\title{
Effect of post-weld tempering treatment on performance of DP600 spot welded joint
}

\section{Uticaj obrade otpuštanjem nakon zavarivanja na osobine tačkasto zavarenog spoja dvofaznog čelika DP600}

\author{
Stručni rad / Professional paper \\ Rad je u izvornom obliku objavljen u okviru 72. IIW godišnje \\ Skupštine $i$ međunarodne konferencije održane u Bratislavi- \\ Slovačka 07-12. Jula 2019 \\ Rad primljen / Paper received: \\ Oktobar 2020.
}

Prevod izvornog rada na srpski jezik: Z. Odanovic
Adresa autora / Author's address:

${ }^{1}$ Beijing University of Technology, College of Materials Science and Engineering, Beijing, China

${ }^{2}$ Hefei General Machinery Research Institute, College of Materials Science and Engineering, Hefei, China

alih_bjut@163.com,

b/xs_bjut@163.com,

c1481202485@qq.com,

d13910321588@139.com

Ključne reči: čelik DP600, elektrootporno tačkasto zavarivanje, obrada otpuštanjem, zamorna čvrstoća

\section{Rezime}

U cilju postizanja povećanih zahteva automobilske industrije za čvrstoćom i osobinama materijala korišćenih u proizvodnji, porasla je primena naprednih čelika visoke čvrstoće za izradu panela za karoserije vozila, posebno od dvofaznih čelika. Tačkasto elektrootporno zavarivanje je glavni proces spajanja pri proizvodnji karoserija vozila. Način unapređenja zatezne čvstoće i osobina otpornosti na zamor elektrootporno tačkasto zavarenih spojeva dvofaznih čelika je od velikog značaja za zavarene konstrukcije karoserija. U ovom radu, ispitivano je elktrootporno tačkasto zavarivanje hladno valjanog dvofaznog čelika, pri struji zavarivanja u opsegu od 9000A12000A. Poređeni su efekti otpuštanja nakon zavarivanja na mikrostrukturu, mikrotvrdoću, smicanje i zamor spojeva. Rezultati pokazuju da se mikrosturkturne transformacije dešavaju u oblasti sočivastog šava otpuštanjem nakon zavarivanja i da otpušteni martenzit koji se javlja, snižava mikrotvrdoću sočivastog šava, a prečnik šava, zatezno-smicajna čvrstoća i enrgija loma su više u odnosu na one bez obrade otpuštanjem. Otpuštanje poboljšava zamornu čvrstoću tačkastog spoja i bez obzira da li je otpušten, prsline se stvaraju uz zonu uticaja toplote spoja nakon ispitivanja zamaranjem. 


\section{Introduction}

In order to meet the needs of the automotive industry for the light weight and safety performance of the car body, the development of lightweight high-strength advanced highstrength steel has become the key to lightweight technology [1]. As a typical representative of the first generation of advanced high-strength steel, Dual Phase steel has the advantages of high strength, good elongation, formability, and strong absorption of collision energy. Now it has become the most extensive high-strength steel material used in the body weight reduction trend. It is mainly used in automotive parts requiring high strength, strong impact absorption resistance and good forming performance, such as hood, frame and wheel. With the advancement of steel properties and forming technology, Dual Phase steel is also used in parts such as interior and exterior panels of automobiles [2].

At present, in the manufacture of advanced high-strength steel sheet structures for automobile bodies, the spot welding process is relatively mature. Many studies on advanced highstrength steel resistance spot welding mainly focuses on the weldability of various steels, the influence of welding specification parameters on the microstructure of spot joints, the optimization of welding procedures and processes, etc., aiming to improving the quality of joints from the perspective of adjustment of welding process parameters. 590 $\mathrm{MPa}, 600 \mathrm{MPa}, 780 \mathrm{MPa}$ dual-phase steels have been confirmed to be welded by resistance spot welding, and A. Chaboket al. [3] found that doublepulse spot welding can also achieve high-strength connection of $1000 \mathrm{MPa}$ grade dual-phase steel; Tai-I Hsuet al.[4] compared the joint performance of the DP780 resistance spot welding and the friction stir spot welding. It was found that a larger spot joint area and a higher joint strength can be achieved by resistance spot welding; Besides the same material of dual-phase steel, Jian bin Chen]et al.[5] also studied the resistance spot welding of DP600 and 5052 aluminum alloy; S. H. Mousavi Anijdan et al. [6] studied the spot welding of DP600 with stainless steel. Taguchi method was used to design the experiments and Minitab software was used to analyze the effect of parameters and obtain an optimum condition. For the influence of parameters on spot welding of dual-phase, Mohsen et al. [7] analyzed the effects of welding current, welding time, electrode pressure and electrode size on the performance of DP600 joints; Wang et al.[8] used finite element simulation to analyze the

\section{Uvod}

$U$ cilju postizanja zahteva automobilske industrije za smanjenjem težine i sigurnosti karoserija vozila, razvoj lakih, naprednih čelika visoke čvrstoće je postao glavni imperativ tehnologija smanjenja težine [1]. Kao izraziti predstavnik prve generacije naprednih čelika visoke čvrstoće, dvofazni čelik (DP) imao je prednosti visoke čvrstoće, dobrog izduženja, plastičnosti i visoke absorbcije energija sudara. On je postao najčešće korišćeni čelični materijal visoke čvrstoće u cilju smanjenja težine. On se uglavnom koristi za delove vozila koji zahtevaju visoku čvrstoću, visoku otpornost na snažne udare, kao i dobre osobine za oblikovanje, za delova kao što su hauba, šasija i točkovi. Sa prednostima koje karakterišu čelike i razvijene tehnologije oblikovanja dvofaznog čelika (DP), omugućavaju njegovu primenu za delove kao što su unutrašnji i spoljašnji paneli automobila [2].

$\mathrm{U}$ proizvodnji naprednih struktura za karoserije automobila od čeličnih limova visoke čvrstoće, proces tačkastog zavarivanja je relativno sazreo. Mnoge studije o otpornom tačkastom zavarivanju naprednih čelika visoke čvrstoće, uglavnom su se usresredile na zavarljivost različitih vrsta čelika, uticaj parametara zavarivanja na mikrostrukturu tačkastog spoja, optimizaciju procedura i procesa zavarivanja i slično, imajući za cilj poboljšanje kvaliteta spoja iz ugla podešavanja parametara procesa zavarivanja. Za dvofazne čelike klase 590 $\mathrm{MPa}, 600 \mathrm{MPa}$ i $780 \mathrm{MPa}$, potvrđeno je da se uspešno zavaruju otpornim tačkastim zavarivanjem, a A. Chaboket i dr. [3] su našli da duplo pulsirajuće tačkasto zavarivanje može takođe da postigne spoj visoke čvrstiće i kod dvofaznih čelika klase $1000 \mathrm{MPa}$. Tai-I Hsuet i dr. [4] su poredili osobine spoja čelika DP780 koji su tačkasto zavareni i zavarenih postupkom zavarivanja trenjem sa mešanjem. Pokazano je da se može postići veća oblast tačkastog spoja i veća čvrstoća tačkastim otpornim zavarivanjem. Pored ispitivanja spajanja istih materijala - dvofaznih čelika, Jian bin Chen]et i dr.[5] su ispitivali tačkasto otporno zavarivanje dvofaznog čelika DP600 i aluminijumske legure 5052. S. H. Mousavi Anijdan i dr. [6] su ispitivali tačkasto zavarivanje čelika DP600 sa nerđajućim čelikom. Taguchi metod je korišćen za kreiranje eksperimenata, a Minitab softver primenjen za analizu uticaja parametara na tačkasto zavarivanje dvofaznih čelika. Mohsen i dr. [7] analizirali su efekte jačine struje, vremena zavarivanja i pritiska i veličine elektroda na osobine spojeva čelika DP600. Wang i dr.[8] su koristili simulaciju metodom konačnih elemenata da bi 
influence of pitting and size increase on the quality of DP590 dual-phase steel resistance spot welding. The results show that the two tip shapes will seriously affect the quality of the solder joints, so that the pull - shear strength is reduced. Li Hong et al. [9] studied the DP600 spot welding process and obtained the spot welding window and the best welding specifications. Zhang et al. [10] analyzed the failure modes of dual-phase steel resistance spot welded joints of different thicknesses, pointing out that tensile stress causes interface failure and shear stress causes pull failure.

However, advanced high-strength steel represented by dual-phase has a low carbon content and a high alloying element content [11]. During resistance spot welding, molten hightemperature austenite is rapidly cooled. (about $2000 \mathrm{oC} / \mathrm{s}$ ) During the formation of nugget, the temperature curve will directly cross the martensite transformation critical region, and different contents and distribution of martensite will be produced in the nugget [12]. These martensites will make the nuclear hardness becomes higher and the brittleness increases. On the other hand, the cooling phase transformation produces defects such as pores, cracks and uneven internal stress distribution [13], which not only reduces the static load strength of the joint, but also shortens the low cycle fatigue life [14].

How to improve the problems mentioned above, in addition to adjust the welding process specifications, postweld treatment is a relatively good method. Wei shidong of Harbin Institute of Technology [15] found that the strength and plasticity of the dual-phase steel plate were significantly reduced after welding. The post-weld tempering treatment can eliminate the internal stress and transform the structure, thus improving the plasticity. M.S. Zhao et al. [16] found that proper post-weld heat treatment can improve the ductility and maximum bearing capacity of the workpiece. If the specimen is overheated, although the plasticity is likely to increase, the bearing capacity will be seriously degraded. Researches prove that the multi-pulse tempering process can fully temper the high stress area of the spot joint, and obtain the ductile fracture morphology. The mechanical properties, especially the fatigue performance, can be significantly improved.

Based on this research, this paper studies the effect of post-weld pulse tempering on the performance of cold rolled dual-phase steel DP600 resistance spot welded joints. Microstructure observation, hardness test, shear test and fatigue analizirali uticaj pitinga i povećanja dimenzija na kvalitet tačkastog zavarivanja dvofaznog čelika DP590. Rezultati su pokazali da dva različita oblika vrha elektroda značajno utiču na kvalitet spoja, pa je zatezno smicajna čvrstoća smanjena. Li Hong i dr. [9] su ispitivali proces tačkastog zavarivanja čelika DP600 i dobili su najoptimalnije parametre zavarivanja. Zhang i dr. [10] analizirali su modele loma elektrootporno tačkasto zavarenih spojeva dvofaznih čelika različitih debljina, ističući da zatezni naponi uzrokuju medjupovršinski lom i da smicajni naponi prouzrokuju zatezne lomove.

Napredni čelici visoke čvrstoće predstavljeni dvofaznim čelicima imaju nizak sadržaj ugljenika i visok sadržaj legirajućih elemenata [11]. Za vreme elektrootpornog tačkastog zavarivanja, tečan visoko temperaturni austenit se brzo hladi brzinom od oko 2000 oC/s. Za vreme formiranja sočivastog šava, temperaturna kriva direktno prolazi kroz kritičnu oblast martenzitne transformacije i različita količina i raspodela martenzita nastaje u spoju [12]. Ovaj martenzit daje povišenje tvrdoće i krtosti. Sa druge strane, fazne transformacije pri hlađenju proizvode greške kao što su pore, prsline i neujednačenu raspodelu unutrašnjih napona [13], koji ne samo da smanjuju statičku čvrstoću spoja pri opterećenju, već skraćuju niskociklični zamorni vek [14].

Kako bi prevazišli gore pomenute probleme, a u cilju podešavanja karakteristika procesa zavarivanja, termička obrada nakon zavarivanja je relativno dobar metod. Wei Shidong iz Harbin Institute of Technology [15] je našao da se čvrstoća i plastičnost dvofaznih čeličnih limova značajno smanjuje nakon zavarivanja. Termički tretman otpuštanjem nakon zavarivanja, može da eliminiše unutrašnja naprezanja i da transformiše strukturu, čime se poboljšava plastičnost. M.S. Zhao i dr. [16] našli su da podesnom termičkom obradom nakon zavarivanja mogu da se poboljšaju plastičnost $i$ naveća nosivost radnog komada. Ako se komad pregreje, iako izgleda da plastičnost raste, nosivost će biti značajno umanjena. Istraživači su potvrdili da proces otpuštanja u više ciklusa može da potpuno otpusti viske napone u oblasti tačkastog spoja i da se dobije duktilna morfologija loma. Mehaničke osobine, posebno osobine loma, mogu da se značajno unaprede.

$\mathrm{Na}$ osnovu ovih istrživanja, u radu su izučavani efekti procesa otpuštanja u više ciklusa na osobine spoja hladno valjanog dvofanog čelika DP600 koji je zavaren elektrootpornim tačkastim zavarivanjem. Ispitivanja mikrostrukture, tvrdoće, smicajne čvrstoće i zamora su izvršena na otpuštenim test 
are carried out on the tempered joint. It was found that after post-weld tempering treatment, martensite transformation occurred in the microstructure of the joint, the hardness and brittleness phase decreased, and the shear strength and fatigue strength of the joint were improved.

\section{Experiment}

Cold-rolled DP600 dual-phase steel which is cut into $100 \mathrm{~mm} \times 30 \mathrm{~mm} \times 1 \mathrm{~mm}$ is chosen for the study and the joint length of the spot welded joint is 30 $\mathrm{mm}$. The nominal composition of this steel is shown in Tab. 1. From the metallographic structure (Fig. 1 ), we can see that the DP600 dual-phase steel is mainly composed of martensite and ferrite. The martensite is uniformly distributed on the ferrite matrix in island shape, showing obvious metal fiber flow lines. Soft ferrite and martensite are coexisted, and a small amount of light blue bainite exists on the martensite matrix at the ferrite interface. spojevima. Utvrđeno je da nakon tretmana otpuštanjem posle zavarivanja, martenzitna transformacija se dešava u mikrostrukturi spoja i da se količina tvrdih i krtih faza smanjuje, čime se smicajna i zamorna čvrstoća spoja poboljšavaju.

\section{Eksperiment}

Hladno valjani dvofazni čelik DP600, isecan je $u$ uzorke dimenzija $100 \mathrm{~mm} \times 30 \mathrm{~mm} \times 1 \mathrm{~mm}$, koji su izabarani za ispitivanja, a dužina spoja tačkasto zavarenog spoja je bila $30 \mathrm{~mm}$. Nominalni sastav ispitivanog čelika je prikazan u Tabeli 1 . Iz metalografskih struktura prikazanih na slici 1 , može se videti da je dvofazni čelik DP600 uglavnom sastavljen od martenzita i ferita. Martenzit je ravnomerno raspoređen u feritnoj osnovi u obliku ostrva, pokazujući očigledne linije trakavosti. Konstatovano je prisustvo ferita i martenzita, kao i mali udeli svetlo plavog beinita koji se javlja u martenzitnoj osnovi na feritnim međupovršinama.

Table 1. Composition (mass fraction, \%) and mechanical properties of DP600

Tabela 1. Hemijski sastav (u masenim udelima, \%) i mehaničke osobine čelika DP600

\begin{tabular}{|c|c|c|c|c|c|}
\hline $\mathrm{C}$ & $\mathrm{Mn}$ & $\mathrm{Si}$ & $\begin{array}{c}\text { Carbon equivalent } \\
\text { Ugljenični ekvivalent/Ceq }\end{array}$ & $\begin{array}{c}\text { Tensile strength } \\
\text { Zatezna čvrstoća }\end{array}$ & $\begin{array}{c}\text { Yield strength } \\
\text { Granica tečenja }\end{array}$ \\
\hline 0.1 & 1.6 & 0.3 & 0.37 & $\geq 600 \mathrm{MPa}$ & $\geq 350 \mathrm{MPa}$ \\
\hline
\end{tabular}

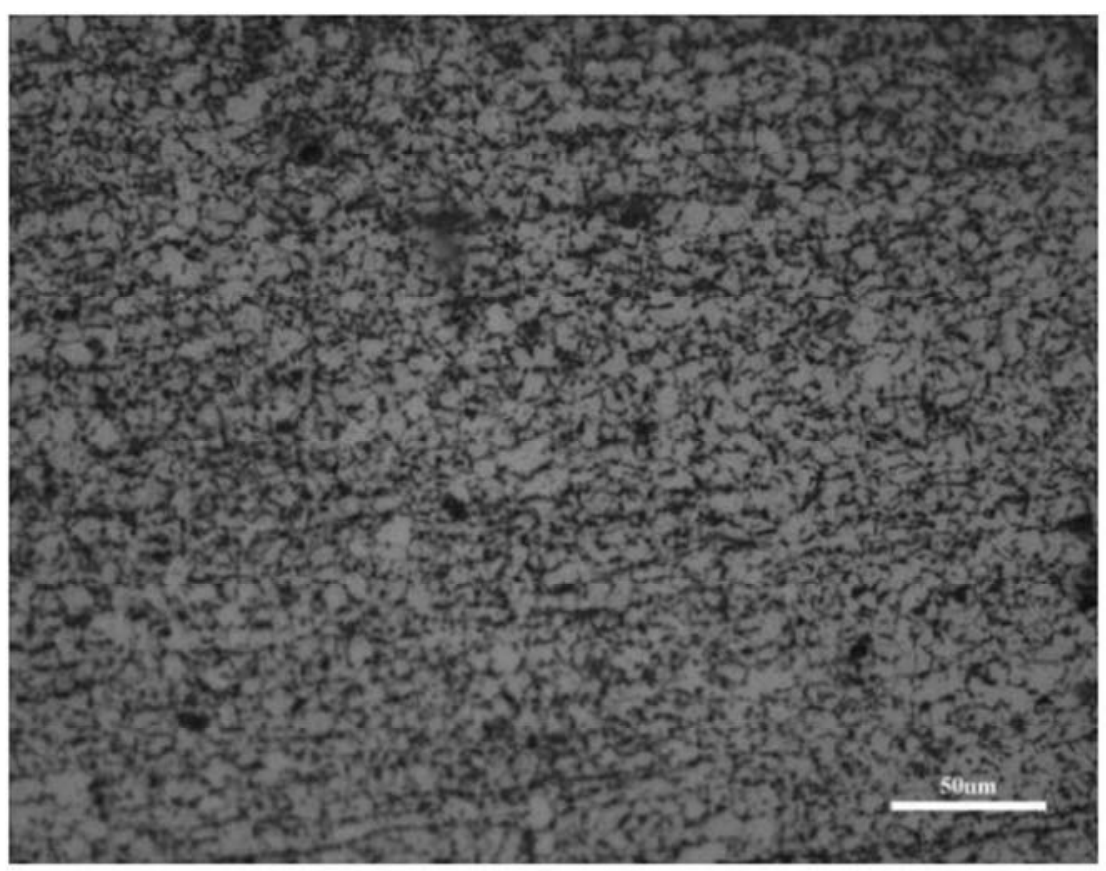

Figure 1. The microstructure of DP600

Slika 1. Mikrostruktura čelika DP600 
Spot welding was performed using a ZPDN-90 medium frequency inverter resistance spot welding machine operating in the range of welding time is $200 \mathrm{~ms}$, electrode force is $3500 \mathrm{~N}$ and welding current is $9000 \mathrm{~A}-12000 \mathrm{~A}$. Then the workpieces were tempered with the time is $700 \mathrm{~ms}$, temperature current is $6000 \mathrm{~A}$. The metallographic sample was prepared at the maximum crosssectional area of the joint, then etched with $4 \%$ nitric acid alcohol solution, the microstructure of the structure was observed under OLYMPUS-BX51M metallographic microscope and OLYMPUS-SZ61 stereo microscope.

Mechanical properties of the spot welds are characterized using hardness profile, tensile test and fatigue test. Vickers hardness profile is measured along the diagonal direction of the spot welding sample, passing through the base material zone, the heat affected zone, the nugget zone and the heat affected zone with an indenting load of 200 $\mathrm{g}$, a loading time of $10 \mathrm{~s}$ and the distance of 0.2 $\mathrm{mm}$. Fig. 2 is the testing track of micro-hardness.
Tačkasto zavarivanje izvršeno je srednje frekventnim invertorskim uredjajem ZPDN-90 za tačkasto zavarivanje, sa vremenom zavarivanja od $200 \mathrm{~ms}$, silom pritiska elektroda od $3500 \mathrm{~N}$ i strujom zavarivanja od $9000 \mathrm{~A}-12000 \mathrm{~A}$. Zatim su uzorci otpuštani u vremenu od $700 \mathrm{~ms}$, sa strujom od 6000A. Metalografski uzorci su pripremani iz maksimalne oblasti poprečnog preseka spoja. Nakon toga su nagrizani sa $4 \%$ rastvorom azotne kiseline $u$ alkoholu i mikrostruktura je analizirana na metalografskom mikroskopu OLYMPUS-BX51M i stereo mikroskopu OLYMPUS-SZ61.

Mehaničke osobine tačkastih spojeva su određivane ispitivanjem tvrdoće, ispitivanjem zatezanjem i ispitivanjem zamorom. Linije na kojima je ispitivana Vikers trdoća su duž pravca dijagonale tačkasto zavrenog uzorka, prolazeći kroz osnovni metal, zonu uticaja toplote, metala šava i ponovo kroz zonu uticaja toplote. Merenje je vršeno sa opterećenjem od $200 \mathrm{~g}$, vremenom opterećenja od 10s i sa medjusobnim rastojanjem između otisaka od $0.2 \mathrm{~mm}$. Na slici 2 su prikazane linije ispitivanja mikro tvrdoće.
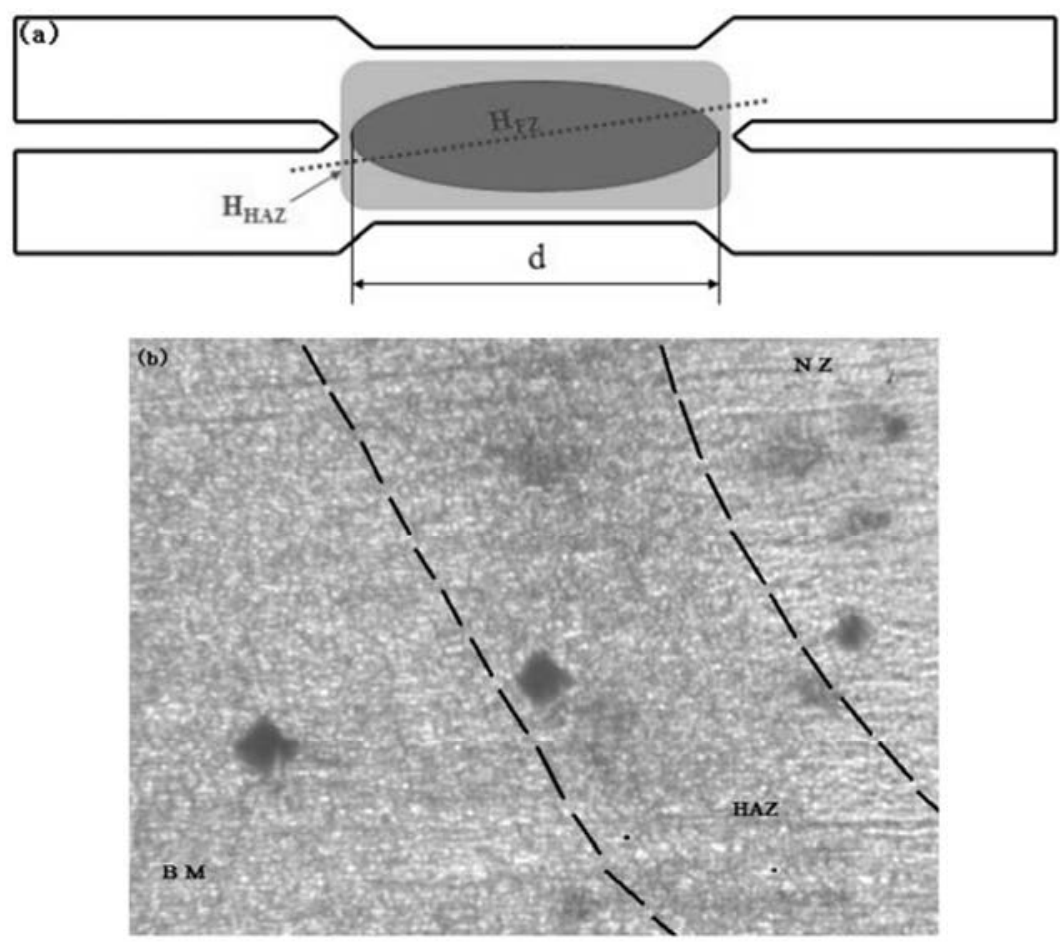

Figure 2. The micro-hardness detection track: (a) sketch of hardness testing track; (b) hardness testing track under microscope

Slika 2. Linije ispitivanja mikro tvrdoće: a) šematski prikaz linija ispitivanja tvrdoće; b) linija ispitivanja tvrdoće na mikroskopu

Tensile and fatigue tests were performed at room temperature with the MTS-810 Material Test System. Fig. 3 is the dimension of tensile-shear and fatigue specimens. Tensile tests were performed with a tensile strength speed of $5-6$
Isptivanja zatezanjem i ispitivanja zamorom su vršena na sobnoj temperaturi sa sistemom za ispitivanje matrijala MTS-810. $\mathrm{Na}$ slici 3 su prikazane dimenzije uzoraka za ispitivanje smicanja zatezanjem i ispitivanja zamorom. Ispitivanje 
$\mathrm{mm} / \mathrm{min}$ and fatigue tests were performed with a frequency of $5-20 \mathrm{~Hz}$ and a force ratio $\mathrm{Rp}$ $(=$ Pmin/Pmax $)=0.1$. In addition, the test was interrupted every $1 \times 107$ cycles. Peak load (measured as the peak point in the loaddisplacement curve) and failure energy (measured as the area under the load-displacement curve up to the peak load) were extracted from the loaddisplacement curve. The failure energy (energy absorption) was obtained by integrating the area under the load-displacement curve up to the peak load using the following equation(2-1)[17]:

Faihure energy $=\sum_{n=1}^{N} F(n)[X(n)-X(n-1)] \cdots \cdots(2-1)$

where $\mathrm{F}$ is load, $\mathrm{X}$ is the displacement, $\mathrm{n}$ is the sampled data and $N$ is the peak failure load. The data points for peak load and failure energy are the average of three samples.

The fatigue strength was obtained using the following equation(2-2) [18]:

$$
\delta_{R(N)}=\frac{1}{m} \sum_{i=1}^{n} V_{i} \delta_{i} \cdots \cdots(2-2)
$$

Where $m$ is the total number of effective tests; $n$ is the level of stress level; $\delta_{\mathrm{i}}$ is the ith stress level; $V_{i}$ is the number of tests at the ith stress level; $\delta_{R(N)}$ is the stress corresponding to $10^{\wedge} 7$ cycles. zatezanjem vršeno je sa brzinom zatezanja od 5-6 $\mathrm{mm} / \mathrm{min}$, a ispitvanja zamorom su vršena sa frekvencijom od $5-20 \mathrm{~Hz}$ i odnosom sila od $\mathrm{Rp}$ $(=P \min / \mathrm{Pmax})=0.1$. Dodatno su ispitivanja prekidana svakih $1 \times 10^{7}$ ciklusa. Maksimalno opterećenje (mereno na vršnoj tački krive opterećenje - pomeranje) i energija loma (merena kao površina ispod krive opterećenje - pomeranje do vršnog opterećenja) koja je dobijena iz krive opterećenje - pomeranje. Energija loma (absorbovana energija) je dobijena integraljenjem površine ispod krive opterećenje - pomeranje do vršnog opterećenja primenom sledeće jednačine $(2-1)[17]:$

Faihure energy $=\sum_{n=1}^{N} F(n)[X(n)-X(n-1)] \cdots \cdots(2-1)$

Gde je $F$ - opterećenje, $X$ je pomeranje, $n$ je uzorkovan podatak i $\mathrm{N}$ je vršno opterćenje loma. Podaci za vršno opterćenje i energija loma su srednje vrednosti tri uzorka.

Čvrstoća loma je dobijena primenom sledeće jednačine (2-2) [18]:

$$
\delta_{R(N)}=\frac{1}{m} \sum_{i=1}^{n} V_{i} \delta_{i} \cdots \cdots(2-2)
$$

Gde je $m$ ukupan broj testova, $\mathrm{n}$ je nivo napona, $\delta_{\mathrm{i}}$ je i-ti nivo napona, $V_{i}$, je broj ispitivanja na i-tom nivou napona, $\delta_{R(\mathrm{~N})}$ je napon koji odgovara $10^{\wedge} 7$ ciklusa.

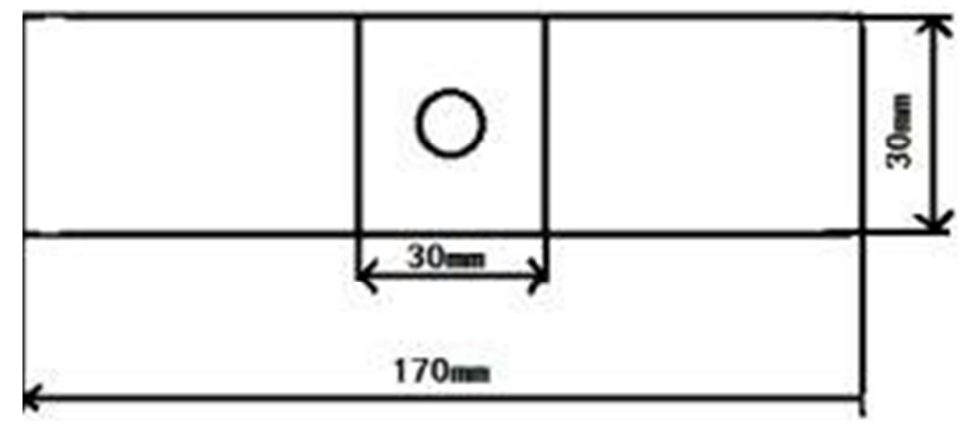

Figure 3. Dimension of tensile-shear and fatigue specimens

Slika 3. Dimenzije uzoraka za ispitivanje smicanja zatezanjem i ispitivanje zamorom

\section{Results and discussion}

\subsection{Microstructure and microhardness}

Fig. 4 shows the microstructure of the nugget area before and after tempering at the welding current: $12000 \mathrm{~A}$, welding time: $200 \mathrm{~ms}$, welding load: $3500 \mathrm{~N}$. It can be seen that acicular martensite occurred in the tempered nugget area while there are mainly lath martensite in without tempered nugget zone.

\section{Rezultati i diskusija}

\subsection{Microstruktura i mikrotvrdoća}

Slika 4 pokazuje mikrostrukturu sočivastog šava pre i posle otpuštanja pri struji zavarivanja od 12000 A, vremenu zavarivanja od 200 ms, pritisku elktroda pri zavarivanju od $3500 \mathrm{~N}$. Može se videti da se igličasti martenzit javlja u oblasti otpuštenog sočivastog šava, dok je uglavnom lamelarni martenzit u neotpuštenoj zoni sočivastog šava. 

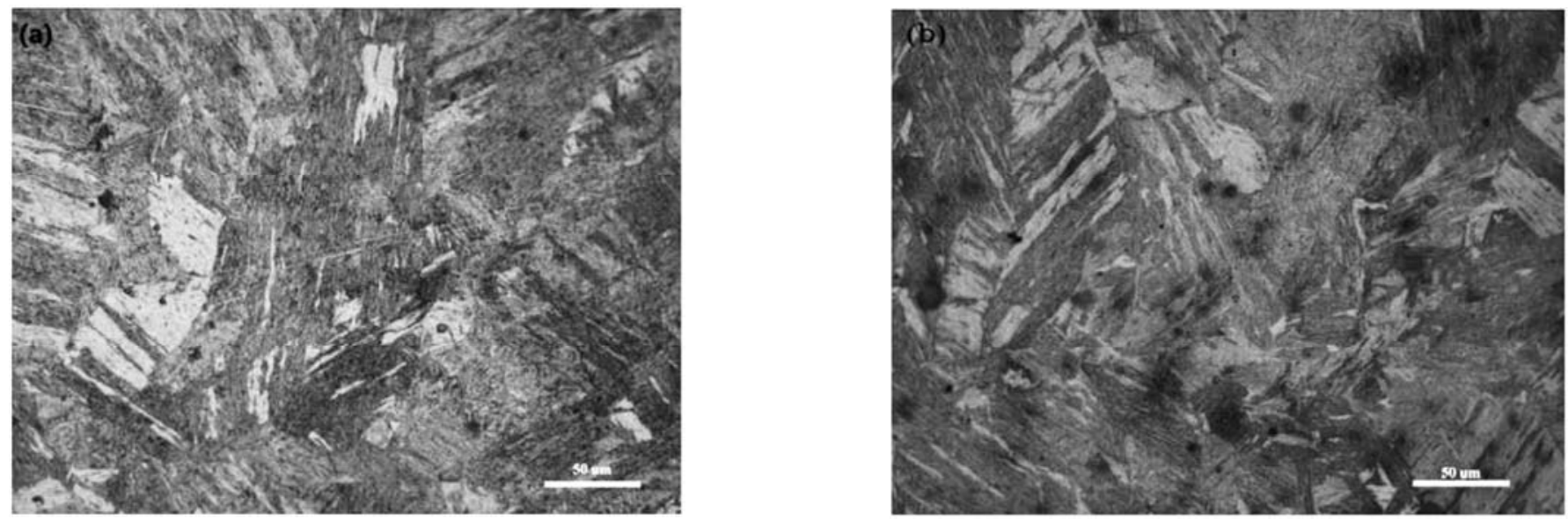

Figure 4. Microstructure of nugget area before and after tempering: (a) without tempering; (b) tempered

Slika 4. Mikrostruktura sočivastog šava pre i posle otpuštanja: a) bez otpuštanja; b) nakon otpuštanja

After the microhardness test, as shown in Fig. 5, it was found that the microhardness of the nugget after the tempering treatment decreased slightly, which indicate that the microstructure of the nugget region changed. The acicular martensite structure may be tempered martensite.
Nakon ispitivanja mikrotvrdoće, kao što je prikazano na slici 5 , konstatovano je da je mikrotvrdoća sočivastog šava nakon tretmana otpuštanja neznatno smanjena, što ukazuje da je promenjena mikrostruktura oblasti sočivastog šava. Struktura igličastog martenzita, mogla bi da bude otpušteni martenzit.

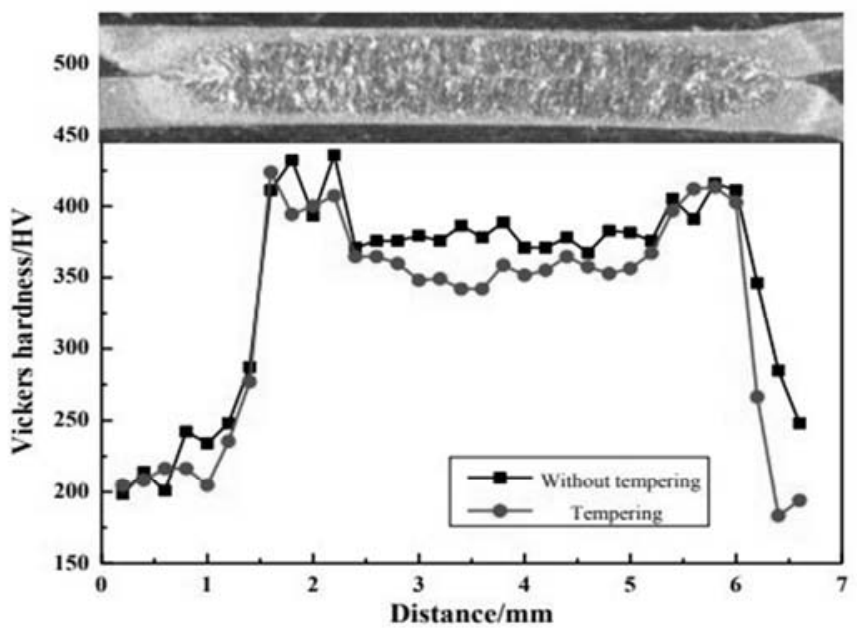

Figure 5. Microhardness testing results, with and without temepering

Slika 5. Rezultati merenja mikrotvrdoća, pre i posle otpuštanja

\subsection{Mechanical Properties}

Fig. 6 shows the measurement schematic diagram of nugget diameter. Fig. 7 is the welding current-nugget diameter relationship before and after tempering. It can be seen that before and after tempering, the welding current is 9000 12 000A, the diameter of the nugget increases with the increase of current and all the nugget diameters reach $A$ grade, which is classified by Automotive industry and the United States RWMA on spot welding nugget, as shown in Tab. 2 ( $\delta$ is the thickness of the base material) [19]. This phenomenon is related to the welding heat input.

\subsection{Mehaničke osobine}

Slika 6 šematski prikazuje merenje prečnika sočivastog šava. Slika 7 prikazuje odnos struje zavarivanja i prečnika sočivastog šava pre i posle otpuštanja. Može se videti pre i posle otpuštanja, pri struji zavarivanja 9000 12000A, da se prečnik sočivastog šava povećava sa povećanjem jačine struje i da svi prečnici sočivastog šava dostižu $A$ kvalitet, koji je klasifikovan od strane Automobilske industrije i SAD RWMA za tačkasti sočivasti šav, kao što je prikazano u Tabeli 2 . ( $\delta$ je debljina osnovnog materijala) [19]. Ovaj fenomen je uslovljen unosom toplote zavarivanja. 
When the welding current is small, the welding heat input will be reduced, the heating at the spot area will be insufficient, and the molten metal will be less, which directly leads to the smaller diameter of the weld nugget. As the welding current increases, the heat input increases, and the resistance heat is sufficient to melt more metal to form a high-quality nugget. The diameter of the nugget is inevitably increased. Xinge Zhang [20] and Xiaodong WAN [21] also pointed that if the welding current is too big, the expansion speed of the nugget diameter greatly exceeds the expansion speed of the plastic ring, splash will occur at the solder joint, and defects will be generated inside the nugget.
Kada je struja zavarivanja mala, unos tolote zavarivanja biće smanjen, i zagrevanje u oblasti tačkastog spoja će biti nedovoljno, što direktno dovodi do manjeg prečnika sočivastog šava. Sa povećanjem jačine struje zavarivanja, unos toplote se povećava, toplota nastala otporom je dovoljna da istopi više metala i stvori visoko kvalitetan sočivast šav. Prečnik sočivastog šava se neizbežno povećava. Xinge Zhang [20] i Xiaodong WAN [21] su takođe naglasili da ako je struja zavarivanja suviše visoka, brzina širenja prečnika sočivastog šava značajno prelazi brzinu širenja okolnog mekanog prstena i prskanje će se desiti u spoju koji očvršćava, čime će se formirati greška unutar sočivastog šava.

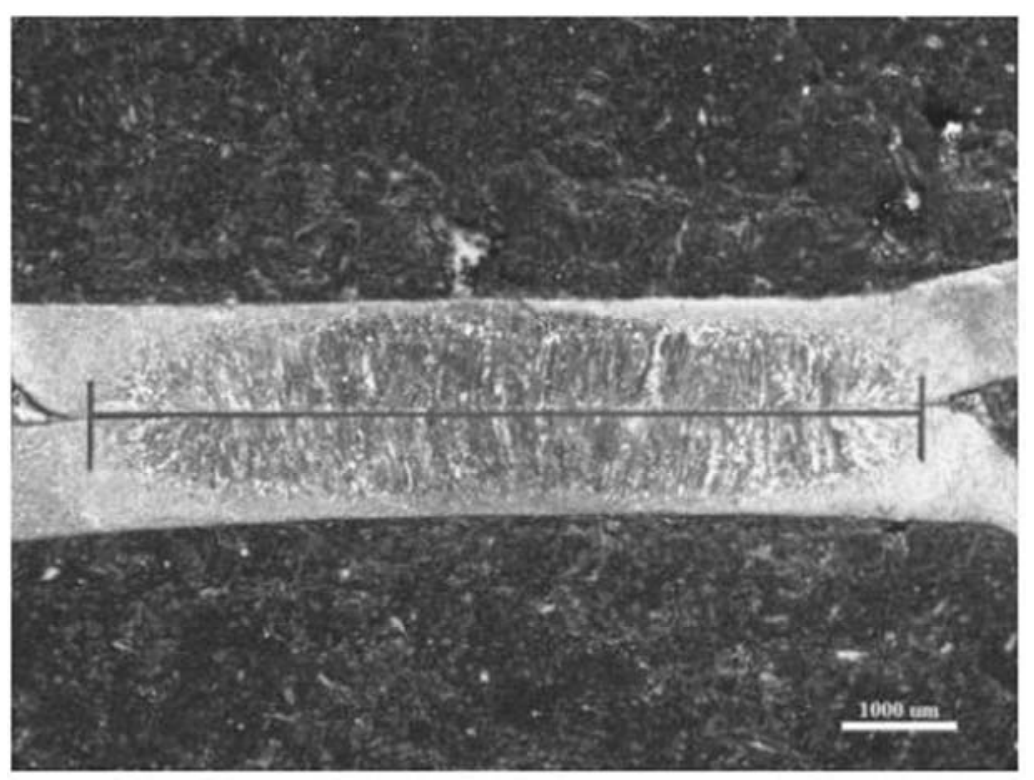

Figure 6. Measurement schematic diagram of nugget diameter

Slika 6. Šematski dijagram merenja prečnika sočivastog šava

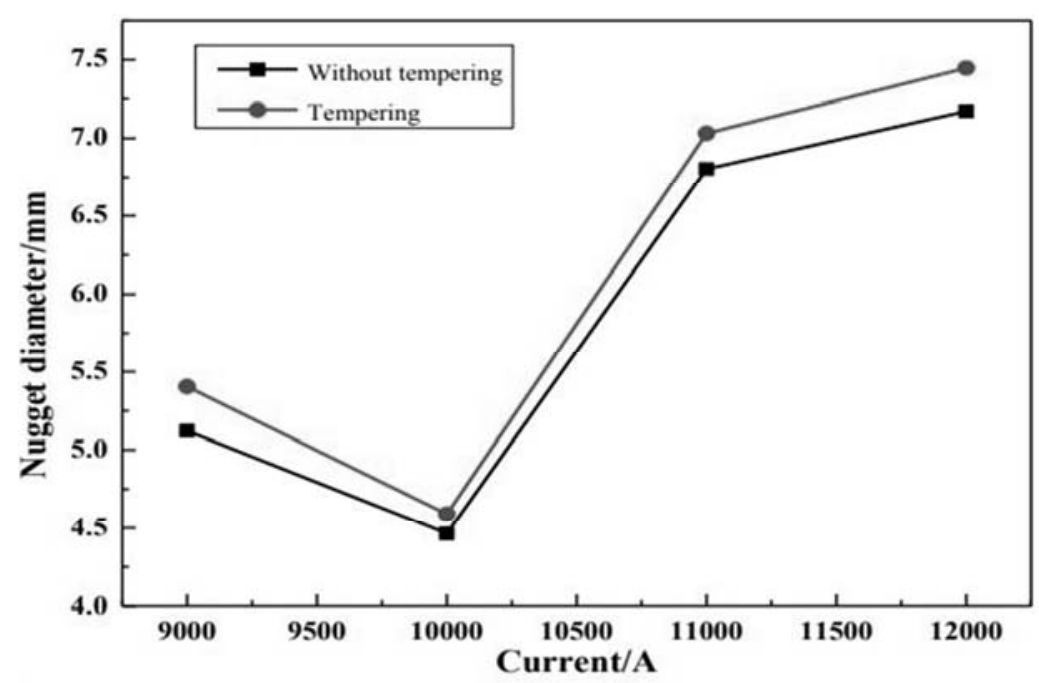

Figure 7. Welding current-nugget diameter relationship before and after tempering

Slika 7. Zavisnost struje zavarivanja - prečnik sočivastog šava, pre i nakon otpuštanja 
Table 2. The classification of nugget [19]

Tabela 2. Klasifikacija sočivastog šava [19]

\begin{tabular}{|c|c|c|c|}
\hline Grade/ Kvalitet & $A$ & $B$ & $C$ \\
\hline Diameter/ Prečnik & $5 \sqrt{ } \delta$ & $4 \sqrt{ } \delta$ & $3 \sqrt{ } \delta$ \\
\hline Area/ Površina & $19.62 \delta$ & $12.56 \delta$ & $7.065 \delta$ \\
\hline
\end{tabular}

Then we can find the spot weld nugget diameter without tempering is smaller than the tempered. Thus by post-weld tempering, we can obtain a larger spot joint. As studied by A.S. Baskoro et al. [22] that the diameter of the nugget has a great influence on the shear load of the spot welded joint. The larger the joint area, the larger the load it can bear. Fig. 8 shows the average tensile-shear force of the joint increases with the continuous increase of the welding current. Under the condition of tempering treatment, the maximum tensileshearing force is $14.01 \mathrm{kN}$ when the welding current is 12 $000 \mathrm{~A}$, while the maximum tensile-shearing force is $12.84 \mathrm{kN}$ under the condition of without tempering treatment. Moreover, the average tensile shear force of the sample with tempered treatment is greater than that without tempering sample under the same parameters. Fig. 9 reveals the displacement distance of the tempered sample is much larger than that without tempering. It can be seen from the Fig. 10 that as the welding current increases, the failure energy of the sample increases continuously, but the absorption of the tempered sample is greater than that has not been tempered. The maximum failure energy of the tempered and without tempered samples occurred when the welding current was $12000 \mathrm{~A}$, which was $56.94 \mathrm{~kJ}$ and $45.26 \mathrm{~kJ}$, respectively.
Tako se dešava da je tačkasti spoj sočivastog šava bez otpuštanja manji nego otpušteni. Nakon otpuštanja nakon zavarivanja, može se dobiti veći tačkasti spoj. Prema radu A.S. Baskoro i dr. [22], prečnik sočivastog šava ima veliki uticaj na smicajnu silu zavarenog tačkastog spoja. Što je veća oblast spoja, to je veće opterećenje koje može da nosi spoj. Slika 8. pokazuje da srednja sila zatezanje - smicanje raste sa konstantnim povećanjem struje zavarivanja. $U$ uslovima tretmana otpuštanjem maksimalna sila je $14.01 \mathrm{kN}$ kada je struja zavarivanja $12000 \mathrm{~A}$, dok je maksimalna sila zatezanje - smicanje $12.84 \mathrm{kN} u$ uslovima bez tretmana otpuštanja. Šta više srednja zatezno - smicajna sila kod uzoraka tretiranih otpuštanjem je veća nego bez otpuštanja uzorka pod istim uslovima. Slika 9 prikazuje da je rastojanje pomeranja (smicanja) otpuštenih uzoraka mnogo veće nego bez otpuštanja. Iz slike 10. može se videti da kada struja zavarivanja raste, energija loma uzorka kontinualno raste, ali i da je absobovana energija otpuštenog uzorka viša nego kod onih koji nisu otpušteni. Najveća energija loma otpuštenih i neotpuštenih uzoraka se postiže kada je struja zavarivanja $12000 \mathrm{~A}$, odnosno iznosila je $56.94 \mathrm{~kJ}$ and $45.26 \mathrm{~kJ}$, respektivno.

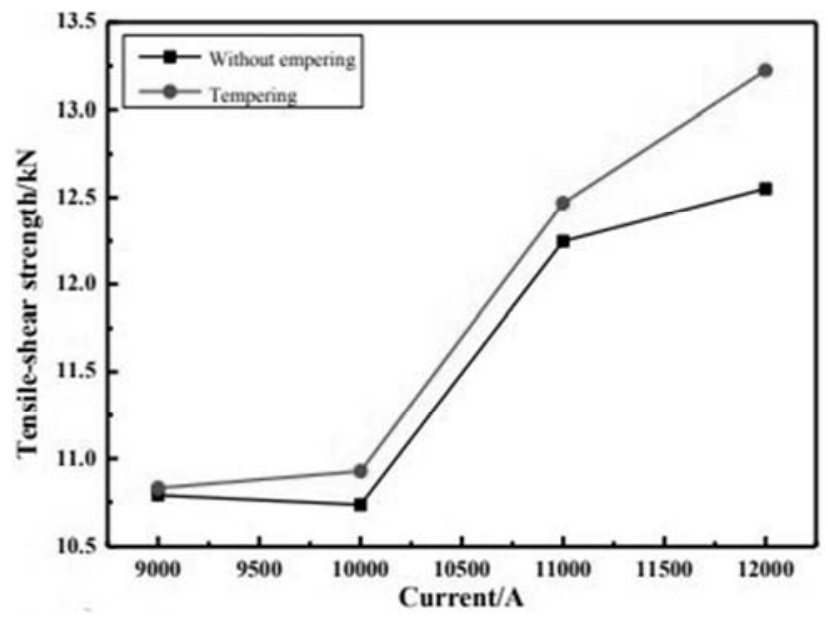

Figure 8. Welding current tensile-shear force of joint before and after tempering

Slika 8. Zavisnost struja zavarivanja i zatezno-smicajna sila spoja pre i nakon otpuštanja 


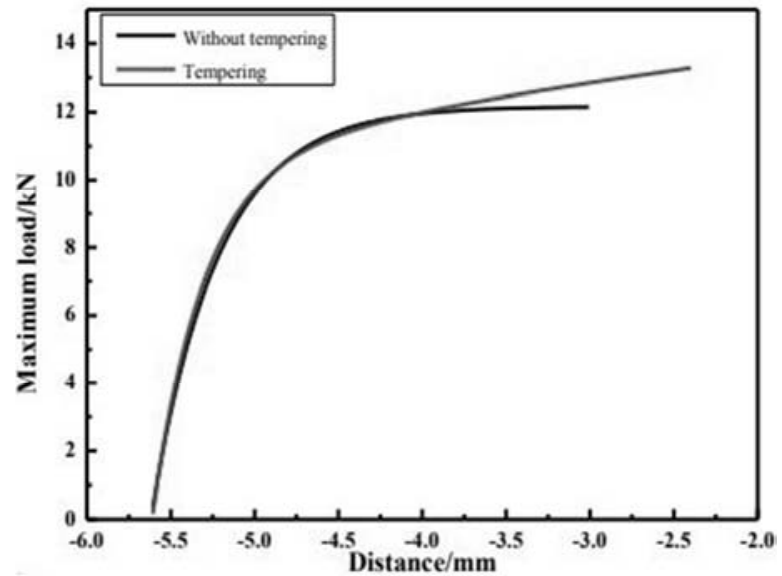

Figure 9. Tensile-shear force-displacement curves of joint before and after tempering at the welding current: 12000A, welding time: $200 \mathrm{~ms}$, welding load: $3500 \mathrm{~N}$

Slika 9. Krive zavisnosti zatezno smicajne sile od pomeranja spoja (smicanja) pre i nakon otpuštanja pri struji zavarivanja od 12000A, vreme zavarivanja 200ms, sila zavarivanja $3500 \mathrm{~N}$

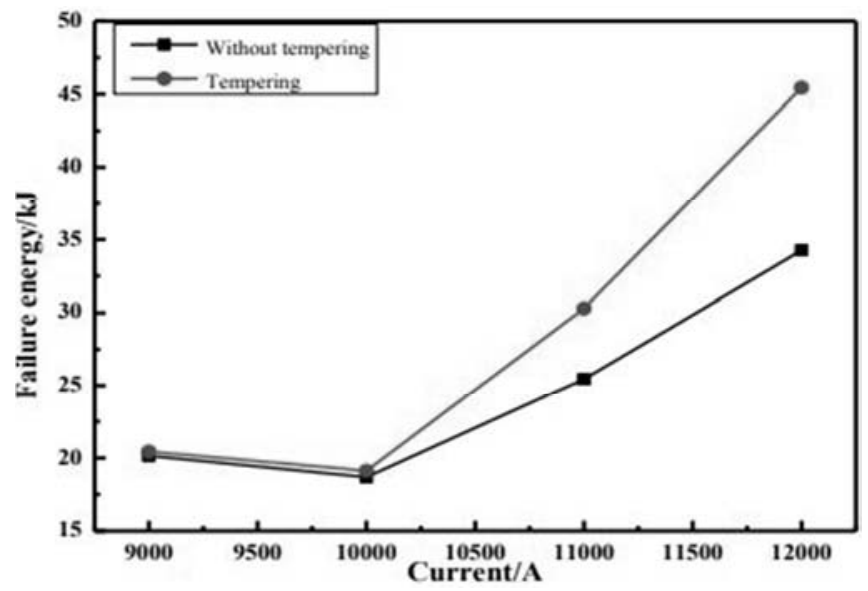

Figure 10. Welding current- failure energy of joint before and after tempering

Slika 10. Zavisnost struje zavarivanja - energija loma pre i nakon otpuštanja

The above results indicate the tempering treatment has a great influence on the mechanical properties of the spot welded sample. The change of tensile-shear strength is not only related to the joint size, but also related to the change of the microstructure in weld nugget area after tempering. Postweld tempering treatment can reduce the brittle quenching structure in the base metal, slow down the cooling rate of the spot joint and improve the mechanical properties [23].

\subsection{Fatigue Properties}

The spot welding parameters used in this fatigue test are 2 groups, of which the welding current is 12 $000 \mathrm{~A}$, the welding time is $200 \mathrm{~ms}$, the pressure is 3 $500 \mathrm{~N}$, and the other was operated by post-weld tempering with the current is $6000 \mathrm{~A}$, and the time is $700 \mathrm{~ms}$.
Gornji rezultati ukazuju da tretman otpuštanjem ima veliki uticaj na mehaničke osobine tačkasto zavarenih uzoraka. Promena zatezno smicajne čvrstoće nije jedino zavisna od veličine spoja, već zavisi i od promena mikrostrukture u oblasti sočivastog šava zavarenog spoja posle otpuštanja. Tretman otpuštanjem nakon zavarivanja može da smanji količinu krtih struktura zakaljivanja u osnovnom materijalu, usporavajući brzine hlađenja tačkastog spoja i time poboljša mehaničke osobine [23].

\subsection{Osobine otpornosti na zamor}

Dve grupe parametara zavarivanja su primenjene za ispitivanja otpornosti na zamor. Prva grupa ispitivana je na uzorcima zavarenim sa strujom zavarivanja od 12000 A,vremenom zavarivanja od $200 \mathrm{~ms}$ i pritiskom elektroda od $3500 \mathrm{~N}$, dok je druga grupa otpuštana nakon zavarivanja sa srtujom od $6000 \mathrm{~A}$ u vremenu od $700 \mathrm{~ms}$. 
Fig. 11 shows the fatigue curve of Spot welding joint before and after tempering. According to the equation (2-2), the joint fatigue strength of the tempered joint is $1.53 \mathrm{kN}$, and the fatigue strength without tempering is $1.18 \mathrm{kN}$. Postweld tempering treatment eliminates the residual stress of the joint and improving the fatigue strength of the joint.

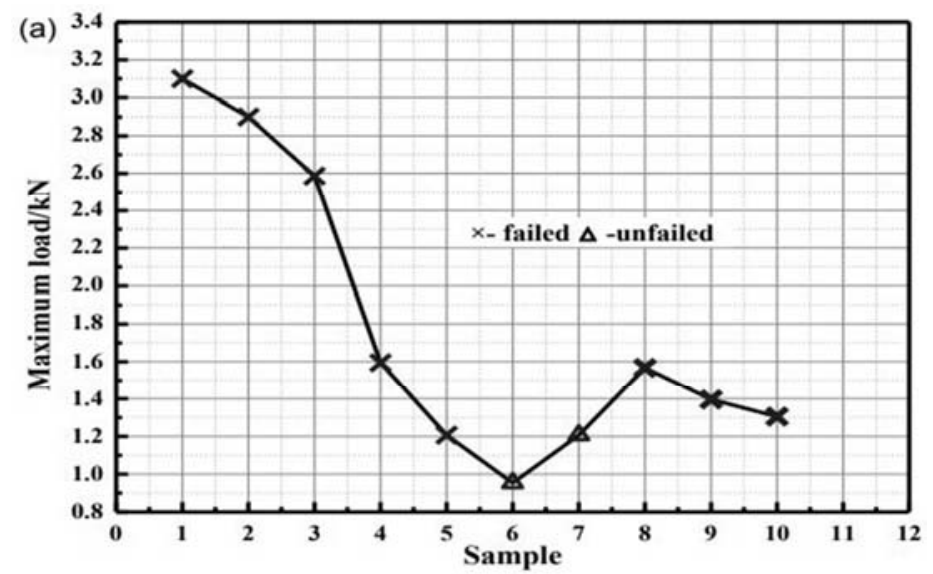

Slika 11 pokazuje krive zamora tačkastih spojeva pre i nakon otpuštanja. Prema jednačini (22), zamorna čvrstoća otpuštenog spoja je $1.53 \mathrm{kN}$, a zamorna čvrstoća bez otpuštanja je $1.18 \mathrm{kN}$. Otpuštanje nakon zavarivanja eliminiše zaostale napone u spoju i poboljšava zamornu čvrstoću spoja.

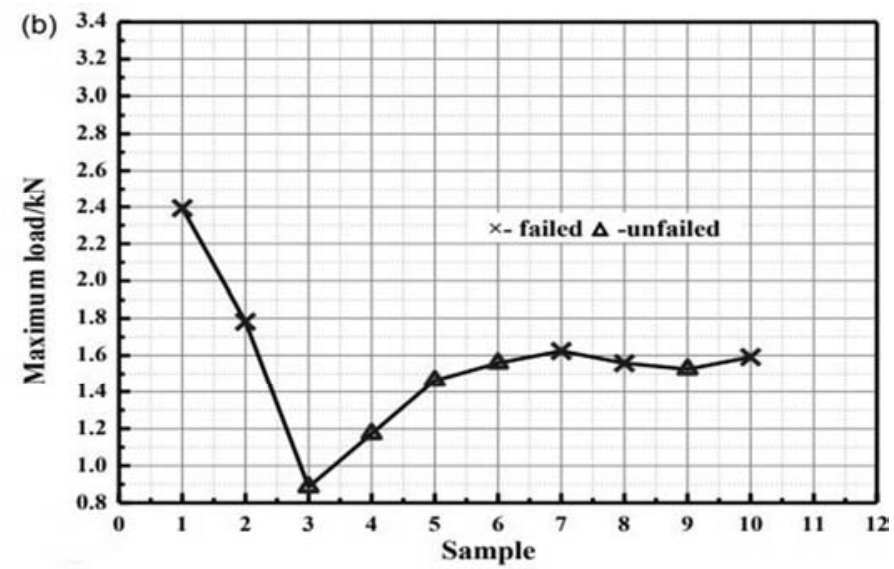

Figure 11. Fatigue curve of DP600 spot welding joint, (a) Fatigue curve of DP600 spot welding joint with tempering, (b) Fatigue curve of DP600 spot welding joint without tempering

Slika 11. Kriva ispitivanja zamaranjem za tačkasti zavaren spoj za čelik DP600, a) Kriva zamaranja za tačkasti zavaren spoj za čelik DP600 sa otpuštanjem, b) Kriva zamaranja za tačkasti zavaren spoj za čelik DP600 bez otpuštanja

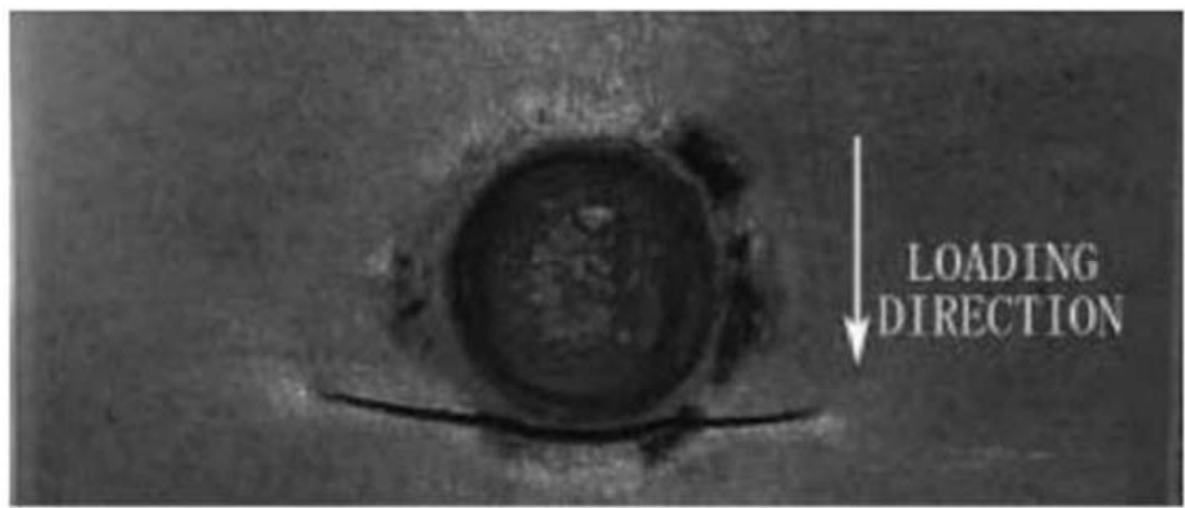

Figure 12. Image of the sampled joint after fatigue testing

Slika 12. Slika uzorka spoja nakon ispitivanja zamorom

Post-weld tempering treatment eliminates the residual stress of the joint and improving the fatigue strength of the joint. Whether the welded joint is tempered or not, it is found the cracks are generated near the weld heat affected zone, as shown in Fig. 12. The crack extends outward from the nugget boundary extending to the base material region and perpendicular to the loading direction. It indicates that the boundary between the base material and the weld nugget is the tip of the crack, and there is a large stress concentration near the heat affected zone.
Tretman otpuštanja nakon zavarivanja uklanja zaostale napone spoja i poboljšava zamornu čvrstoću spoja. Bez obzira da li je otpušten ili nije, konstatovano je da se prsline stvaraju blizu zone uticaja toplote, kao što je prikzano na slici 12. Prslina se prostire spolja od granice sočivastog šava, šireći se u oblast osnovnog materijala poprečno na pravac opterećenja. To ukazuje da je granica između osnovnog materijala i sočivastog šava $u$ stvari vrh prsline, i da postoje velike koncentracije napona uz zonu uticaja toplote. 


\section{Conclusions}

The effect of post-weld heat treatment on the performance of DP600 resistance spot welding joint is investigated. The following conclusions are made.

1. Post-weld tempering treatment brings the change of microstructure, tempered martensite occurred in the nugget, which reduces the microhardness of the weld nugget;

2. By post-weld tempering, we can obtain a larger spot joint and the mechanical properties, like tensile-shear strength and failure energy, is improved;

3. Post-weld tempering treatment eliminates the residual stress of the joint and improving the fatigue strength of the joint. All of the fatigue crack extends outward from the nugget boundary extending to the base material region and perpendicular to the loading direction.

\section{Acknowledgements}

The authors would like to acknowledge Dr. Hong Li for guiding the whole research. We also would like to acknowledge the financial support provided by Fundamental Research Funds for Beijing Municipal Universities (PXM2019_014204_500032)

\section{References}

[1] Evaluation Technologies on High strength steel sheet for Automobiles, Kobelco research institute, http://www.kobelcokaken.co.jp/en/example/c/index.html

[2] Nesa Raj S O Kumaran D and Sundar S S S P 2018 IOP Conference Series Materials Science and Engineering 402.

[3] Chabok A Van d A E and De Hosson J T M 2017 Materials \& Design 124 171-182.

[4] Hsu T I Wu L T and Tsai M H 2018 The International Journal of Advanced Manufacturing Technology 53152.

[5] Jianbin Chen Xinjian Yuan and Zhan Hu 2017 Journal of Manufacturing Processes, 30 396-405.

[6] Mousavi Anijdan S H Sabzi M and Ghobeiti-Hasab M 2018 Materials Science and Engineering: A 726 120125.

[7] Eshraghi M Tschopp M A and Asle Zaeem M 2014 Materials \& Design 56 387-397

[8] Wang B Hua L and Wang X 2016 International Journal of Advanced Manufacturing Technology 83(912) 1917-1926.

[9] Tao B H Li H and Meng X J 2011 National Welding Conference of China.

[10] Zhang H Qiu X and Xing F 2014 Materials \& Design 55 366-372.

[11] W ilson H Farshid P and Veena S 2018 Metals 8(4) 199.

\section{Zaključci}

Efekat termičke obrade nakon zavarivanja na osobine elektrootporno zavarenog spoja čelika DP600 je ispitivana i prikazana u radu. Sledeći zaključci mogu da se izvedu.

1. Tretman otpuštanjem nakon zavarivanja dovodi do promene mikrostrukture, otpušteni martenzit se javlja u sočivastom šavu, čime se smanjuje njegova mikrotvrdoća.

2. Primenom otpuštanja nakon zavarivanja dobija se veći tačkasti spoj i mehaničke osobine, kao zatezno-smicajna čvrstoća i energija loma se poboljšavaju.

3. Tretman otpuštanjem nakon zavarivanja eliminiše zaostale napone spoja i poboljšava zamornu čvrstoću spoja. Sve zamorne prsline šire se van granica sočivastog šava, šireći se u oblast osnovnog materijala $i$ poprečno na pravac opterećenja.

\section{Zahvalnica}

Autori bi želeli da se zahvale Dr. Hong Li-u za vođenje celokupnog istraživanja. Takode se zahvaljujemo finansiskoj podršci obezbeđenu od strane Fundamental Research Funds for Beijing Municipal Universities (PXM2019_014204_500032)

[12] Paveebunvipak K and Uthaisangsuk V 2018 Materials \& Design 160 731-751.

[13] Liang X Yuan X and Wang H 2016 International Journal of Precision Engineering and Manufacturing 17(12) 1659-1664.

[14] Lara J H O and Ambriz R R 2017 Proceedings of the 17th International Conference on New Trends in Fatigue and Fracture.

[15] Wei S D Lv D X and Liu D 2014 Science and Technology of Welding and Joining 19 427-435.

[16] Zhao M S Chiew S P and Lee C K 2016 Journal of Constructional Steel Research 122 167-177.

[17] Pouranvari M and Marashi S P H 2010 Science and Technology of Welding and Joining 15(2) 149-155.

[18] Han X H Liu S L and Zhao Y Q 2013 China Railway Science 34(6) 84-88.

[19] Standards and Testing, http : // www . spottrack.eu / welcome/ standards - testing.jsp

[20] Zhang X G Yao F B and Ren Z H 2018 Materials 112310

[21] Wan X D Wang $Y X$ and Zhang P 2014 ISIJ International 54 2375-2379

[22] Baskoro A S Trianda M R and Istiyanto J 2015 International Conference on Electrical Engineering \& Computer Science. IEEE

[23] Wei S T and Lu S P 2017 Transactions of the China Welding Institution 08 118-138 